\title{
Analisis Pengaruh Ukuran Perusahaan, Karakter Eksekutif, dan Kepemilikan Manajerial Terhadap Agresivitas Pajak (Studi Pada Perusahaan Pertambangan yang Terdaftar di Bursa Efek Indonesia Tahun 2014-2017)
}

\author{
Hellen Widya Putri' ${ }^{1}$, Desi Handayani², dan Dedy Djefris ${ }^{3}$ \\ ${ }^{1}$ Jurusan Akuntansi, Politeknik Negeri Padang \\ Email: hellenwidyaputri@gmail.com \\ ${ }^{2}$ Jurusan Akuntansi, Politeknik Negeri Padang \\ ${ }^{3}$ Jurusan Akuntansi, Politeknik Negeri Padang
}

\begin{abstract}
ABSTRAK
Penelitian ini bertujuan untuk menguji pengaruh ukuran perusahaan, karakter eksekutif, dan kepemilikan manajerial terhadap agresivitas pajak. Variabe independen yang digunakan dalam penelitian ini adalah ukuran perusahaan, karakter eksekutif, dan kepemilikn manajerial. Variabel dependen dalam penelitian ini adalah agrsivitas pajak yang diukur menggunakan ukuran effective tas rate (ETR). Populasi dalam penelitian ini berjumlah 38 perusahaan pertambangan yang terdaftar di Bursa Efek Indonesia (BEI) selama periode 2014-2017. Penentuan sampel pada penelitian ini menggunakan purposive sampling dan memperoleh sampel sebanyak 15 perusahaan pertambangan. Analisis data yang digunakan adalah regresi berganda dengan bantuan SPSS versi 20. Hasil penelitian menunjukkan karakter eksekutif berpengaruh terhadap agresivitas pajak, sedangkan ukuran perusahaan dan kepemilikan manajerial tidak berpengaruh terhadap agresivitas pajak.
\end{abstract}

Kata Kunci: Agresivitas Pajak, Ukuran Perusahaan, Karakter Eksekutif, Kepemilikan Manajerial

\begin{abstract}
This study aimed to examine the effect of size of firm, executive character, and managerial ownership to tax aggressiveness. The independent variabels used in this study are size of firm, executive character, and managerial ownership. The Dependent variable in this study is tax aggressiveness that measured using the effective tax rate (ETR). Population teken as object obsevation 38 mining companies listed in Indonesia Stock Exchange in the 2014-2017 period. Determination of sample was made by applying purposive sampling method and obtaining a sample of 15 mining companies. Analysis of data used is multiple regresion with the help of SPSS version 20. The result showed that the ececutive character had influence on tax aggressiveness, while size of firm and managerial ownership did not effect the tax aggressiveness.
\end{abstract}

Keywords: Tax Aggressiveness, Size of Firm, Executive Character, Managerial Ownership.

\section{PENDAHULUAN}

Pajak merupakan sumber pendapatan terbesar bagi negara yang akan berpengauh terhadap APBN (Anggaran Pendapatan dan Belanja Negara). APBN nantinya akan digunakan untuk memenuhi berbagai macam kebutuhan publik. Sehingga, sudah selayaknya pemerintah menaruh perhatian khusus pada sektor perpajakan. Berbagai upaya telah dilakukan pemerintah demi meningkatkan penerimaan pajak negara, seperti penurunan tarif pajak, penghapusan sanksi administrasi perpajakan, dan 
baru-baru ini pemerintah mengeluarkan kebijakan tax amnesty (pengampunan pajak). Namun fatktanya, target yang di tetapkan pemerintah belum juga tercapai.

Pada tahun 2014 realisasi penerimaan pajak sebesar 1.143 triliun yaitu sekitar 91,73\% dari target pajak yang ditetapkan pemerintah sebesar 1.246,1 triliun (Waluyo, 2015). Pada tahun 2015 persentase penerimaan pajak pemerintah menurun menjadi 81,52\% atau setara dengan 1.055 triliun dari target pajak yang ditetapkan 1.294,25 triliun (Ariyanti, 2016). Selanjutnya pada tahun 2016, persentase penerimaan pajak pemerintah hampir sama dengan tahun sebelumnya yaitu sebesar 81,54\% atau 1.105 triliun dari 1.355 triliun (Deny, 2017). Walaupun pada tahun 2016 pemerintah sudah melakukan program tax amnesty (pengampunan pajak) tapi target yang ditetapkan pemerintah belum juga tercapai. Terakhir pada tahun 2017 penerimaan pajak pemerintah sekitar $89,32 \%$ atau sekitar 1.339 triliun dari target pajak sebesar 1.498,97 triliun (Kusuma, 2018).

Kesulitan dalam pencapaian target pajak dikarenakan, pajak merupakan beban bagi perusahaan yang akan mengurangi laba perusahaan. Oleh karenanya, banyak perusahaan dan pemegang saham lebih suka membayar pajak yang kecil dan menggunkan strategi-strategi perpajakan yang agresif. Menurut Frank, Lynch dan Rego (2009) agresivitas pajak merupakan suatu pengelolaan yang ditujukan untuk penurunan laba kena pajak melalui perencanaan pajak baik dengan cara tax avoidance maupun tax evasion.

Seringnya tindakan agresivitas pajak yang dilakukan oleh perusahaan telah membuat banyak peneliti melakukan penelitian megenai agresivitas pajak. Seperti penelitian yang dilakukan oleh Richardson dan Lanis (2007), Hartadinata dan Tjaraka (2013), dan Dewi dan Jati (2014) yang meneliti faktor-faktor yang mempengaruhi agresivitas pajak. Di antara faktor-faktor yang diteliti yaitu ukuran perusahaan, karakter eksekutif, dan kepemilikan manajerial.

Ukuran perusahaan menggambarkan jumlah aset yang dimiliki oleh perusahaan. Semakin besar skala perusahaan maka aktivitas yang terjadi semakin banyak dan laba yang diperoleh akan semakin tinggi. Hal ini akan membuat perusahaan lebih berusaha untuk melakukan agresivitas pajak. Namun tidak semua penelitian yang dilakukan menemukan pengaruh ukuran perusahaan dengan agresivitas pajak. Seperti penelitian yang dilakukan oleh Richardson dan Lanis (2007) dan Annisa (2017) menemukan bahwa ukuran perusahaan tidak berpengaruh terhadap agresvitas pajak, sedangkan penelitian yang dilakukan oleh Tiaras dan Wijaya (2015) menemukan bahwa ukuran perusahaan berpengaruh terhadap agresivitas pajak.

Dewi dan Jati (2014) menemukan bahwa karakter eksekutif berpengaruh terhadap tindakan agresivitas pajak perusahaan. Dimana ada dua karakter eksekutif yaitu risk taker dan risk averse yang tercermin dari besar kecilnyo resiko perusahaan. Semakin besar resiko yang dimiliki perusahaan maka eksekutif cenderung bersifat risk taker, yang artinya dia tidak akan takut untuk mengambil keputusan walaupun keputusan tersebut beresiko tinggi (termasuk melakukan agresivitas pajak) demi keuntungan perusahaan. Terbalik dengan risk taker, risk averse menggambarkan eksekutif yang lebih suka mengambil keputusan yang memiliki resiko rendah. Eksekutif yang memiliki karakter risk taker akan lebih berpengaruh terhadap agresivitas pajak perusahaan dibandingkan dengan eksekutif yang bersifat risk averse.

Kepemilikan manajerial adalah besarnya kepemilikan saham yang dimiliki oleh pihak manajerial perusahaan. Semakin tinggi persentase kepemilikan tersebut 
maka manajer akan termotivasi untuk meningkatkan kinerja dan bertanggung jawab meningkatkan kemakmuran pemegang saham. Sebaliknya, apabila persentase kepemilikan manajerial kecil maka manajer hanya terfokus pada pengembangan kapasitas atau ukuran perusahaan. Penelitian yang dilakukan oleh Rohmansyah (2017) menemukan adanya pengaruh kepemilikan manajerial terhadap agresivitas pajak. Namun beberapa penelitian yang dilakukan menemukan tidak ada pengaruh kepemilikan manajerial dengan agresivitas pajak. Seperti penelitian yang dilakukan oleh Hartadinata dan Tjaraka (2013) menemukan bahwa kepemilikan manajerial tidak berpengaruh terhadap agresivitas pajak. Selanjutnya penelitian yang dilakukan oleh Putri dan Lautania (2016) yang juga menemukan bahwa tidak ada pengaruh kepemilikan manajerial terhadap effective tax rate.

Perusahaan pertambangan merupakan salah satu contoh perusahaan yang melakukan tindakan agresivitas pajak, diantaranya PT Bumi Resources Tbk, PT Kaltim Prima Coal, dan PT Aturmin Indonesia yang diduga oleh Ditjen Pajak melakukan manipulasi pajak tahun 2007 sebersar 2,1 triliun. Selain itu perusahaan yang pernah terhambat kasus pajak, PT Freeport Indonesia yang sampai saat sekarang ini masih sangat lambat pembayaran pajaknya. Dikutip dari klinik pajak (2016), Komisi Pemberantasan Korupsi (KPK) menyebut piutang sektor pertambangan di Indonesia mencapai Rp2,8 triliun. Piutang tersebut berasal dari iuran tetap, royalti, jaminan reklamasi, dan pajak yang belum dibayarkan perusahaan pada negara. Sektor pertambangan juga merupakan penyumbang suap tertinggi setelah sektor konstruksi yang menempati peringkat pertama.

Pada tahun 2017, ketika program tax amnesty selesai dilaksanakan, diketahui bahwa partisipasi wajib pajak dari sektor pertambangan masih sangat minim. Dari data Ditjen Pajak, menemukan hanya ada 967 wajib pajak di sektor minerba dari total 6,001 wajib pajak. Sedangkan di sektor migas, hanya 68 wajib pajak yang ikut pengampunan pajak, dari total 1.114 pembayar pajak. Disisi lain, kontribusi sektor mineral dan batu bara pada penerimaan pajak juga menunjukkan tren penurunan sepanjang 2012-2016, yakni dari 5 persen menjadi 2 persen. Dari Rp28 triliun pada 2012 menjadi hanya Rp16 triliun pada 2016. Selain itu menurut Firdaus dalam CNN Indonesia (2017), menemukan ada indikasi tidak dilaporkannya transaksi ekspor batu bara sepanjang 2006-2016, yaitu sebesasr US\$27,06 atau sebesar Rp365,3 triliun.

Berdasarkan pada fenomena yang terjadi di atas, maka peneliti bermaksud melakukan penelitian dengan judul "Analisis Pengaruh Ukuran Perusahaan, Karakteristik Eksekutif, dan Kepemilikan Manajerial Terhadap Agresivitas Pajak pada Perusahaan Pertambangan yang terdaftar di Bursa Efek Indonesia tahun 20142017."

\section{TINJAUAN LITERATUR}

\section{Agresivitas Pajak}

Menurut Hlaing (2012) mendefenisikan agresivitas pajak sebagai kegiatan perencanaan pajak semua perusahaan yang terlibat dalam usaha mengurangi tingkat pajak yang efektif. Menurut Chen et al. (2010) ada 3 (tiga) manfaat tindakan agresivitas pajak, yaitu: (1) Manfaat efisiensi pajak, (2) Manfaat langsung atau tidak langsung, (3) Manfaat kesempatan bagi manajer untuk manampilkan rent extraction. Sebaliknya, kerugian dari tindakan agresivitas pajak ada 2 (dua) menurut Desai dan Dharmapala (2007) diantaranya: (1) Kemungkinan perusahaan memperoleh sanksi atau penalti, dan (2) Menurunnya harga saham. 


\section{Ukuran Perusahaan}

Bujaki dan Richarson (1997) mendefenisikan ukuran perusahaan sebagai skala atau gambaran mengenai besar atau kecilnya suatu perusahaan yang dapat dinyatakan dalam total aset atau penjualan bersih perusahaan. Menurut Richardson dan Lanis (2007), saat ini terdapat dua teori yang sama kuatnya mengenai hubungan agresivitas pajak dengan ukuran perusahaan, yaitu political powet theory dan political cost theory. Politcal power theory menyatakan bahwa perusahaan besar dengan sumber daya yang dimilikinya dapat memanfaatkan proses politik untuk mencapai penghematan pajak optimal. Sedangkan political cost theory, menyatakan perusahaan yang besar dengan sumber daya yang dimilikinya tidak dapat melakukan penghindaran pajak dikarenakan perusahaan akan menjadi sorotan pembuat kebijakan (pemerintah) dan menjadi korban regulasi dari kebijakan pemerintah.

\section{Karakter Eksekutif}

Eksekutif adalah seseorang yang menduduki posisi tertentu dalam sebuah perusahaan atau suatu organisasi yang mempunyai hak dan wewenang untuk menggerakkan orang lain yang disebut bawahan. Low (2008) menyatakan bahwa dalam menjalankan tugasnya sebagai pimpinan perusahaan seseorang eksekutif memiliki dua karakter yakni sebagai risk taker dan risk averse. Risk taker adalah eksekutif yang lebih berani mengambil risiko dalam menjalankan perusahaannya, karena adanya paham bahwa semakin tinggi risiko yang diambil maka akan semakin tinggi pula keuntungan yang diperoleh. Risk averse adalah eksekutif yang cenderung tidak menyukai risiko sehingga kurang berani dalam mengambil keputusan bisnis. Eksekutif yang bersifat risk averse lebih suka menahan sebagian besar aset yang dimiliki dalam investasi yang lebih aman untuk menghindari pendanaan dari utang.

\section{Kepemilikan Manajerial}

Kepemilikan manajerial merupakan kepemilikan saham perusahaan yang dimiliki oleh pihak manajer, direksi dan dewan komisaris yang dimiliki secara pribadi maupun saham yang dimiliki oleh anak cabang perusahaan serta afiliasinya (Chen et al, 2010). Kepemilikan manajerial dalam perusahaan cenderung berusaha untuk meningkatkan kinerjanya untuk kepentingan saham dan kepentingannya sendiri. Kepemilikan manajer dalam perusahaan akan menyebabkan assymetry information yang memberikan peluang manejer secara leluasa melakukan agresivitas pajak untuk memaksimalkan laba perusahaan, serta dengan adanya kepemilikan manajerial akan mengurangi tindakan oportunis manajer karena menyamakan kepentingan manajer dengan pemilik perusahaan. 


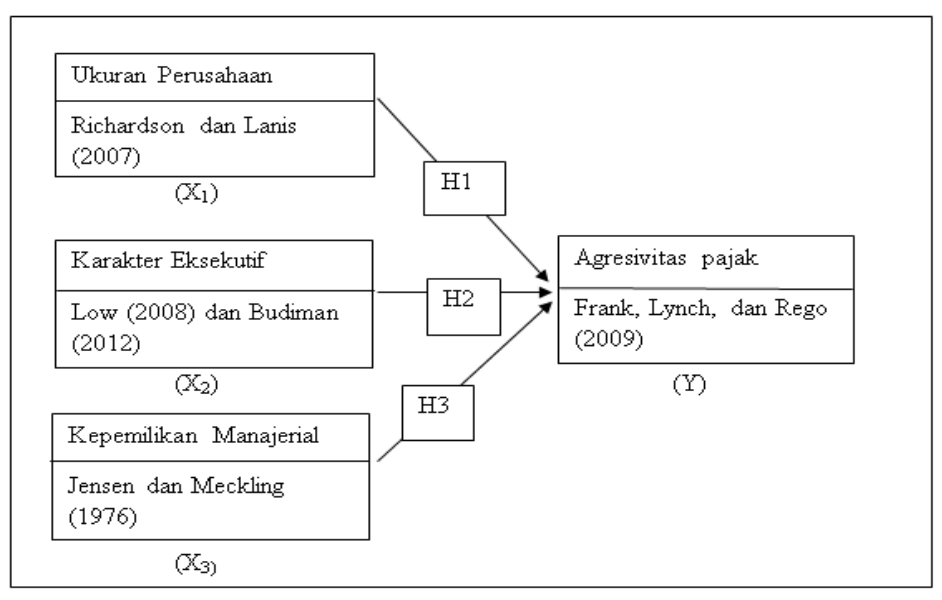

Fambar 2.1: Kerangka Pemikiran, Sumber: Dibangun sebagai dasar pemikiran dalam penelitian ini

\section{Hipotesis Penelitian}

Berdasarkan kerangka konseptual yang telah dikemukakan di atas maka hipotesis penelitian adalah sebagai berikut:

\section{Pengaruh Ukuran Perusahaan Terhadap Agresivitas Pajak}

Ukuran perusahaan dapat diartikan sebagai skala atau gambaran mengenai besar atau kecilnya suatu perusahaan yang dapat dinyatakan dalam total aset atau penjualan bersih perusahaan. Semakin besar ukuran perusahaan maka akan menghasilkan laba yang semakin besar dan tentunya mempengaruhi besarnya pajak yang harus dibayar perusahaan. Perusahaan memiliki kesempatan yang cukup besar dalam melakukan agresivitas pajak. Aset yang dimiliki perusahaan, menggambarkan ukuran perusahaan, semakin banyak aset maka semakin besar ukuran perusahaan. Namun setiap tahunnya aset yang dimiliki perusahaan mengalami penyusutan. Dimana penyusutan tersebut dapat mengurangi laba bersih yang diterima perusahaan, sehingga besarnya beban pajak yang dibayarkan semakin berkurang. Richardson dan Lanis (2007) menyatakan semakin besar ukuran perusahaan maka semakin rendah ETR yang dimiliki perusahaan.

Berdasarkan teori dari penelitian yang dilakukan sebelumnya menyebutkan bahwa semakin besar ukuran perusahaan maka nilai ETR perusahaan semakin kecil, dan juga dapat diambil keputusan bahwa semakin besar ukuran perusahaan maka perusahaan akan lebih leluasa dalam melakukan tindakan agresivitas pajak dengan tujuan menurunkan nilai ETR. Penurunan nilai ETR disebabkan kecilnya beban pajak yang dibayar dibandingkan laba sebelum pajak yang diperoleh perusahaan. Dari penjelasan kerangka pemikiran di atas dan didukung oleh beberapa penelitian, maka hipotesis pertama yang dapat diajukan adalah sebagai berikut:

$\mathrm{H}_{1}$ : Ukuran perusahaan berpengaruh terhadap agresivitas pajak.

\section{Pengaruh Karakter Eksekutif Terhadap Agresivitas Pajak}

Setiap perusahaan memiliki seorang yang memimpin di posisi teratas yang disebut top eksekutif atau top manajer. Dimana top eksekutif itu sendiri memiliki karakter tertentu dalam menjalankan kegiatan perusahaannya untuk mencapai tujuan yang telah ditetapkan perusahaan tersebut. Karakteristik eksekutif tersebut mencerminkan risiko yang akan dihadapi oleh perusahaan. Menurut Low (2008) karakteristik eksekutif terdiri dari risk taker dan risk averse. Dikatakan risk taker apabila seorang manajer mampu mengambil peluang yang mempunyai risiko tinggi, 
sedangkan risk averse terjadi ketika manajer lebih suka memilih peluang yang berisiko rendah. Budiman (2012) menyatakan bahwa, semakin tinggi resiko perusahaan maka eksekutif cenderung bersifat risk taker. Sebaliknya, semakin rendah risiko suatu perusahaan, maka eksekutif cenderung bersifat risk averse. Dewi dan Jati (2014) mengatakan semakin tinggi risiko perusahaan maka perusahaan akan berusaha melakukan perencanaan pajak.

Dilihat dari beberapa pendapat yang disampaikan oleh beberapa peneliti di atas, karakter eksekutif memiliki dampak terhadap agresivitas pajak terutama eksekutif yang bersifat risk taker. Dimana eksekutif dengan karakter tersebut cenderung lebih berani dalam mengambil keputusan, salah satunya melakukan pembiayaan melalui hutang. Selain itu eksekutif dengan karakter risk taker diidentifikasi tidak akan takut mengambil risiko untuk melakukan agresivitas pajak. Berdasarkan pada kerangka pemikiran di atas dan didukung oleh beberapa penelitian, maka hipotesa kedua yang dapat diajukan adalah sebagai berikut:

$\mathrm{H}_{2}$ : Karakter Eksekutif berpengaruh terhadap agresivitas pajak.

\section{Pengaruh Kepemilikan Manajerial Terhadap Agresivitas Pajak}

Manajer dalam sebuah perusahaan memiliki peranan yang penting dalam menjalankan perusahaan, karena manajer perusahaan yang lebih banyak memiliki informasi mengenai perusahaan dapat memberikan keuntungan bagi dirinya yang tidak sejalan dengan kepentingan pemegang saham. Seorang manajemen memiliki keinginan untuk pertumbuhan dan ukuran perusahaan, sedangkan pemegang saham berfokus pada meningkatkan nilai perusahaan. Sehingga dengan adanya pihak manajemen yang menjadi pemegang saham diharapkan pihak manajemen akan lebih berhati-hati dalam melakukan tindakan agresivitas pajak yang dapat merugikan pemegang saham. Karena jika dia salah dalam bertindak pihak yang terkena dampaknya juga dirinya sendiri selaku pemegang saham.

Menurut hasil penelitian yang dilakukan oleh Hartadinata dan Tjaraka (2013) yang menyatakan bahwa kepemilikan manajerial memiliki pengaruh terhadap agresivitas pajak. Dengan adanya kepemilikan saham oleh manajer akan membuat manajemen lebih berhati-hati dalam mengambil keputusan, karena secara tidak langsung manajemen akan merasakan manfaat dan menanggung kerugian dari tindakannya tersebut. Kepemilikan saham yang besar akan membuat manajer lebih memiliki keinginan untuk memonitor atau berupaya lebih giat untuk memenuhi kepentingan pemegang saham yang juga ada dirinya sendiri. Secara teoritis ketika persentase kepemilikan manajerial kecil, maka manajer hanya terfokus pada pengembangan kapasitas atau ukuran perusahaan saja, dengan kata lain perilaku oportunitis manajer akan meningkat. Sehingga secara tidak langsung manajer yang menjadi seorang pemegang saham akan lebih mudah melakukan tindakan agresivitas pajak dikarenakan sebagai pihak yang menjalankan perusahaan manager lebih mengetahui informasi mengenai perusahaan secara keseluruhan. Berdasarkan pada kerangka pemikiran di atas dan didukung oleh beberapa penelitian, maka hipotesa ketiga yang dapat diajukan adalah sebagai berikut:

$\mathrm{H}_{3}$ : Kepemilikan Manajerial berpengaruh terhadap agresivitas pajak.

\section{METODE PENELITIAN Desain Penelitian}

Penelitian ini merupakan penelitian deskriptif kuantitatif yaitu penelitian yang berusaha menjelaskan variabel dengan pengumpulan data-data yang akan 
diolah untuk melihat pengaruh dari variabel tersebut. Penelitian ini juga merupakan penelitian eksplanatory, untuk memperoleh kejelasan fenomena yang terjadi di dunia empiris (real world) dan berusaha untuk mendapatkan jawaban (verificative), yang bertujuan untuk menjelaskan hubungan kausalitas antara variabel-variabel penelitian dan menguji hipotesis yang telah dirumuskan sebelumnya.

\section{Jenis Dan Sumber Data}

Data yang digunakan dalam penelitian ini adalah data sekunder yang bersumber dari dokumentasi perusahaan. Data tersebut berupa data kuantitatif yang diukur dalam skala rasio. Sumber data yang digunakan dalam penelitian ini adalah pada laporan tahunan pada perusahaan pertambangan yang terdaftar di Bursa Efek Indonesia selama periode tahun 2014-2017.

\section{Populasi dan Sampel}

Populasi penelitian ini adalah perusahaan pertambangan yang tercatat di Bursa Efek Indonesia pada tahun 2014-2017 dengan jumlah 38 perusahaan. Berdasarkan kriteria yang digunakan, diperoleh sampel penelitian sebanyak 15 perusahaan. Data diperoleh melalui website www.idx.co.id. Pemilihan sampel dilakukan dengan metode purposive sampling yaitu pengambilan sampel dengan kriteria atau pertimbangan yang ditetapkan dengan harapan peneliti mendapatkan informasi dari kelompok sasaran secara spesifik.

Adapun kriteria-kriteria yang digunakan dalam pemelihan sampel adalah: (1) Perusahaan yang tercatat dan mempublikasikan laporan keuangan selama empat tahun terakhir (2014-2017), (2) Perusahaan yang tidak pernah delisting dari BEI selama periode 2014-2017, dan (3) Perusahaan yang tidak mengalami kerugian atau memperoleh laba selama tahun penelitian.

\section{Definisi Operasional dan Pengukuran Variabel}

Variabel yang digunakan dalam penelitian ini adalah :

1.

Variabel Dependen

Variabel dependen yang digunakan dalam penelitian ini adalah agresivitas pajak. Agresivitas pajak adalah upaya perusahaan untuk meminimalkan beban pajak yang harus dibayar baik dengan cara legal, ilegal atau keduanya. Agresivitas pajak diukur dengan menggunakan proksi effective tax rate (ETR). ETR merupakan proksi yang banyak digunakan pada penelitian-penelitian sebelumnya. Balakrishnan, Bloui, dan Guay (2011) dan Richardson dan Lanis (2012) menggunakan ETR dalam mengukur agresivitas pajak, yang dihitung dengan cara:

$$
\text { ETR }=\frac{\text { Total Beban Pajak Penghasilan }}{\text { Laba Sebelum Pajak }} \times 100 \%
$$

\section{Variabel Independen}

\section{a. Ukuran Perusahaan}

Ukuran perusahaan merupakan tingkat ukuran besar kecilnya suatu perusahaan. Dimana ukuran perusahaan menunjukkan total aktiva yang dimiliki perusahaan. Metode pengukuran yang digunakan untuk mengukur ukuran perusahaan mengacu pada Hartadinata dan Tjaraka (2013) yaitu: 
b. Karakter Eksekutif

Pengukuran karakter eksekutif mengikuti Paligorova (2010) yang menggunakan proksi risiko perusahaan (corporate risk) yang dimiliki perusahaan. Risiko perusahaan dihitung melalui deviasi standar dari EBITDA (Earnig Before Income Tax, Depreciation, and Amortization) dibagi dengan total aset perusahaan. Risiko perusahaan dihitung menggunakan rumus: (Paligorova, 2010:8)

$$
R I S K=\frac{\sqrt{\sum_{T-1}^{T}\left(E-\left(\frac{1}{T} \sum_{T-1}^{T} E\right)=\right.}}{T-1}
$$

Keterangan:

$\mathrm{E}=$ EBITDA (Earnig Before Income Tax, Depreciation, and Amortization)

c. Kepemilikan Manajerial

Kepemilikan manajerial adalah besarnya kepemilikan saham yang dimiliki oleh pihak manajerial. Jensen dan Meckling (1976) menyatakan bahwa semakin besar proporsi kepemilikan saham oleh manajemen dalam suatu perusahaan maka manajemen akan berupaya lebih giat untuk memenuhi kepentingan pemegang saham yang juga ada dirinya sendiri. Pohan (2008) mengatakan bahwa semakin besar proporsi kepemilikan saham oleh manajerial maka akan semakin baik kinerja perusahaan, dikarenakan hal tersebut membantu menyatukan kepentingan pemegang saham dan manajer. Kepemilikan manajerial dapat dihitung dengan menggunakan rasio:

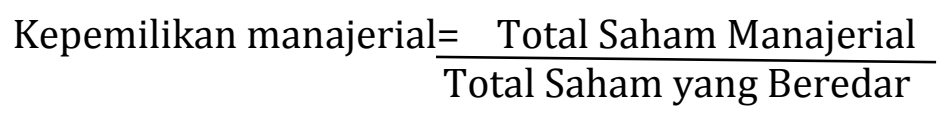

\section{Metode Pengumpulan Data}

Metode pengumpulan data yang digunakan dalam penelitian ini adalah metode studi dokumentasi, dengan memperoleh data berupa laporan tahunan yang dikeluarkan oleh perusahaan pada periode 2014-2017. Pengumpulan data dilakukan dengan melihat data-data yang diperlukan, mencatat, dan menganalisis laporan tahunan pada periode 2014-2017.

\section{Metode Analisis}

Metode analisis data yang digunakan yaitu analisis regresi linier berganda dimana alat bantu statistik yang digunakan yaitu SPSS versi 20. Dalam analisis data terdiri dari: (1) statistik deskriptif, (2)Uji Asumsi Klasik (Uji Normalitas, Uji Multikolinearitas, Uji Heteroskedastisitas, dan Uji Autokorelasi), (3) Anlalisis Regresi Linear Berganda.

Analisis regresi linear berganda dengan persamaan sebagai berikut:

$$
\mathrm{AP}_{\mathrm{it}}=\alpha 0+\beta 1 \text { Size }_{i t}+\beta 2 \text { Riskit }_{\mathrm{it}}+\beta 3 \mathrm{KM}_{\mathrm{it}}+\varepsilon
$$

Keterangan: 


$\begin{array}{ll}\text { AP } & : \text { Agresivitas Pajak } \\ \alpha 0 & : \text { Konstanta } \\ \text { Size } & : \text { Ukuran Perusahaan } \\ \text { Risk } & : \text { Karakter Eksekutif } \\ \text { KM } & : \text { Kepemilikan Manajerial } \\ \beta 1 \ldots \beta 3 & : \text { Koefisien X1..XX } \\ \varepsilon & : \text { Error }\end{array}$

Uji Hipotesis (Uji pengaruh secara simultan (Uji F), Uji Pengaruh secara parsial (Uji t), dan koefisien determinan).

\section{ANALISIS HASIL DAN PEMBAHASAN}

Berikut disajikan hasil uji statistik, Adapun data dan hasil pengelolaannya secara lengkap ada pada penulis

\section{Data Screaning dan Outlier Data}

Data awal yang dimasukkan berupa variabel ukuran perusahaan, karakter eksekutif dan kepemilikan manajerial menunjukkan bahwa residual data tidak memunuhi asumsi normalitas. Untuk itu dilakukanlah outlier data (menghilangkan data yang bernilai ekstrim) yang menyebabkan total sampel yang digunakan untuk penelitian berjumlah 52 sampel dari total sampel yang semulanya berjumlah 60 .

\section{Statistik Deskriptif}

Tabel 4.1

Hasil Uji Statistik Deskriptif Descriptive Statistics

\begin{tabular}{|l|r|r|r|r|r|}
\hline & \multicolumn{1}{|c|}{ N } & Minimum & Maximum & \multicolumn{1}{c|}{ Mean } & Std. Deviation \\
\hline Ukuran_Perusahaann & 52 & 27,5895 & 32,1563 & 29,390615 & 1,2159639 \\
Karakter_Eksekutif & 52 &, 0036 &, 1670 &, 066713 &, 0389005 \\
Kepemilikan_Manajerial & 52 &, 0000 &, 1698 &, 014100 &, 0423865 \\
ETR & 52 &, 2065 &, 7443 &, 339090 &, 1041000 \\
Valid N (listwise) & 52 & & & & \\
\hline
\end{tabular}

Sumber :SPSS 20 dan data sekunder yang diolah

Berdasarkan tabel 4.1 di atas maka dapat diketahui beberapa ukuran deskriptif dari setiap variabel penelitian. ETR (Y), terdapat 52 observasi yang dilakukan pada variabel dimana nilai terkecil 0,2065, nilai terbesar 0,7443. Rata-rata pajak yang dibayarkan perusahaan dari laba sebelum pajak 0,339090 dengan standar deviasi 0,1041000 . Ukuran perusahaan (X1) terdapat 52 observasi yang dilakukan pada variabel dimana nilai terkecil 27,895, nilai terbesar 32,1563. Rata-rata ukuran perusahaan 29,390615 dengan standar deviasi 1,2159639. Karakter Eksekutif (X2) terdapat 52 observasi yang dilakukan pada variabel dimana nilai terkecil 0,0036, nilai terbesar 0,1670. Rata-rata karakter eksekutif bernilai 0,066713 dengan standar deviasi 0,0389005. Kepemilikan Manajerial (X3) terdapat 52 observasi yang dilakukan pada variabel dimana nilai terkecil 0,000 , nilai terbesar 0,1698 . Rata-rata kepemilikan manajerial bernilai 0,0141 dengan standar deviasi 0,0423865.

\section{Uji Asumsi Klasik}

\section{Uji Normalitas}


Uji normalitas dilakukan dengan menggunakan P-Plot Test. Dimana data dikatakan normal apabila data menyebar disekitar garis diagonal dan mengikuti arah diagonalnya.

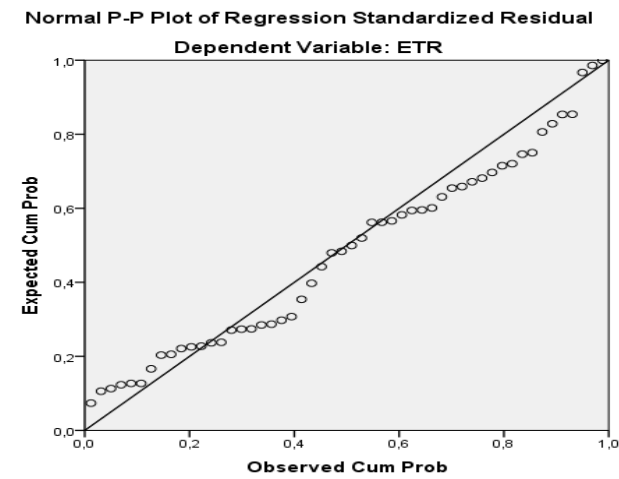

Gambar 4.1. P-Plot Test, Sumber: SPSS 20 dan data sekunder yang diolah Dilihat dari grafik normalitas pada gambar $4.1 \mathrm{di}$ atas terlihat bahwa titik-titik menyebar di sekitar garis diagonal dan penyebarannya mengikuti arah garis diagonal (mengikuti pada wilayah garis linear), hal ini menunujukkan bahwa model regresi layak dipakai karena memenuhi asumsi normalitas.

Hasil ini juga diperkuat oleh uji normalitas menggunakan One-Sampel Kolmogorov-Smirnov Test. Berikut hasil uji normalitas menggunakan OneSampel Kolmogorov-Smirnov Test:

Tabel 4.2

Hasil uji One-Sampel Kolmogorov Smirnov

One-Sample Kolmogorov-Smirnov Test

\begin{tabular}{|ll|r|}
\hline & & $\begin{array}{r}\text { Unstandardize } \\
\text { d Residual }\end{array}$ \\
\hline $\mathrm{N}$ & Mean & 52 \\
Normal Parameters ${ }^{\mathrm{a}, \mathrm{b}}$ & Std. Deviation &, 08963993 \\
& Absolute &, 109 \\
Most Extreme Differences & Positive &, 109 \\
& Negative &,- 080 \\
Kolmogorov-Smirnov Z & &, 784 \\
Asymp. Sig. (2-tailed) & &, 570 \\
\hline
\end{tabular}

a. Test distribution is Normal.

b. Calculated from data.

Sumber : SPSS 20 dan data sekunder yang diolah

Dari tabel 4.2 dapat dilihat nilai signifikansinya adalah sebesar 0,570 yang menunjukkan bahwa nilai signifikansinya lebih besar dari 0,05, sehingga dapat disimpulkan $\mathrm{H}_{\mathrm{a}}$ ditolak dan data terdistribusi secara normal, sehingga model penelitian ini telah memenuhi kriteria uji asumsi klasik normalitas.

\section{Uji Multikolinearitas}

Mendeteksi adanya multikolinearitas, dapat dilakukan dengan melihat nilai tolerance dan variance inflation factor (VIF) serta besar korelasi antara variabel independen. Model dinyatakan terbebas dari gangguan mutikolinearitas jika mempunyai nilai VIF dibawah 10 atau tolerance diatas 0,1. Adapun hasil uji mutikolinearitas dalam penelitian ini sebagai berikut: 
Tabel 4.3

Hasil Uji Multikolinearitas Coefficients $^{\mathbf{a}}$

\begin{tabular}{|l|r|r|r|r|r|}
\hline Model & \multicolumn{2}{|c|}{$\begin{array}{c}\text { Unstandardized } \\
\text { Coefficients }\end{array}$} & $\begin{array}{c}\text { Standardize } \\
\text { d } \\
\text { Coefficients }\end{array}$ & \multicolumn{2}{|c|}{ Collinearity Statistics } \\
\cline { 2 - 6 } & \multicolumn{1}{|c|}{ B } & Std. Error & \multicolumn{1}{c|}{ Beta } & Tolerance & VIF \\
\hline (Constant) &, 404 &, 383 & & & \\
Ukuran_Perusahaan &, 000 &, 013 &, 001 &, 661 & 1,514 \\
Karakter_Eksekutif & $-1,126$ &, 348 &,- 421 &, 914 & 1,094 \\
Kepemilikan_Manajerial &, 459 &, 386 &, 187 &, 625 & 1,600 \\
\hline
\end{tabular}

a. Dependent Variable: ETR

Sumber : SPSS 20 dan data sekunder yang diolah

Berdasarkan tabel 4.3 di atas dapat diketahui bahwa hasil uji multikolinearitas menunjukkan bahwa nilai tolerance di atas 0,1 dan nilai variance inflation factor (VIF) di bawah 10 untuk setiap variabel. Nilai tolerance yang dihasilkan untuk variabel ukuran perusahaan, karakter eksekutif, dan kapemilikan manajerial masing-masing adalah 0.661, 0.914, dan 0.625, sedangkan nilai VIF yang dihasilkan untuk masing-masing variabel ukuran perusahaan, karakter eksekutif, dan kepemilikan manajerial adalah 1.514, 1.094, dan 1.600. Berdasarkan hasil uji multikolinearitas, maka dapat disimpulkan bahwa semua variabel independen dalam model regresi terbebas dari masalah multikolinearitas dan layak digunakan dalam penelitian ini.

\section{Uji Heteroskedastisitas}

Uji heteroskedastisitas dilakukan dengan memplotkan grafik antara SRESIS dan ZPRED dimana gangguan heteroskedasitas akan tampak dengan adanya pola tertentu pada grafik. Berikut hasil uji heteroskedastisitas pada model penelitian ini yang dapat dilihat pada gambar 4.2:

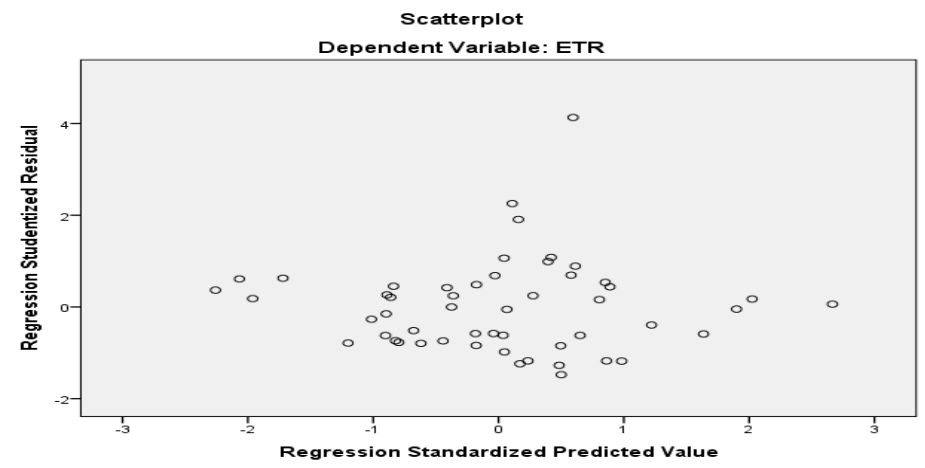

Gambar 4.2: Hasil Uji Heteroskedastisitas

Sumber : Eviews 9 dan data sekunder yang diolah

Dari grafik scatterplots terlihat bahwa titik-titik menyebar secara acak serta tersebar di atas dan di bawah angka nol pada sumbu Y. Dengan demikian, dapat disimpulkan bahwa tidak terjadi heteroskidasitas pada model regresi ini. 


\section{Uji Autokorelasi}

Uji autokorelasi dilakukan untuk menguji apakah dalam model regresi linear ada korelasi antara kesalahan pengganggu pada periode $t$ dengan kesalahan pengganggu pada periode t-1 (sebelumnya). Model regresi yang baik adalah resgresi yang bebas dari autokorelasi. Salah satu cara yang dapat digunakan untuk mendeteksi adanya autokorelasi adalah uji statistik run test. Suatu persamaaan regresi dikatakan terbebas autokorelasi jika nilai signifikan uji statistik run test diatas 0,05. Adapun hasil uji autokorelasi dengan menggunakan uji statistik run test adalah sebagai berikut:

Tabel 4.4

Hasil Uji Run Test

\begin{tabular}{|l|r|}
\hline \multicolumn{2}{|c}{ Runs Test } \\
\hline & $\begin{array}{c}\text { Unstandardize } \\
\text { d Residual }\end{array}$ \\
\hline Test Value &,- 00192 \\
Cases < Test Value & 26 \\
Cases >= Test Value & 26 \\
Total Cases & 52 \\
Number of Runs & 21 \\
Z & $-1,681$ \\
Asymp. Sig. (2-tailed) &, 093 \\
\hline
\end{tabular}

a. Median

Sumber: SPSS 20 dan data sekunder diolah

Dilihat dari tabel 4.4 menunjukkan bahwa nilai sig sebesar 0,093 , nilai sig tersebut besar dari 0,05, hal ini menunjukkan bahwa model regresi tidak terjadi autokorelasi dan layak untuk digunakan dalam penelitian.

\section{Regresi Linier Berganda}

Tabel 4.5

Ringkasan Hasil Pengujian Regresi Linear Berganda

\begin{tabular}{|c|c|c|c|c|}
\hline \multicolumn{5}{|l|}{ Dependent Variable: ETR } \\
\hline Variable & Coefficient & Std. Error & t-hitung & Sig. T \\
\hline $\mathrm{C}$ & 0,404 & 0,383 & 1,055 & 0,297 \\
\hline Ukuran Perusahaan & 0,000 & 0,013 & 0,009 & 0,993 \\
\hline Karakter Eksekutif & $-1,126$ & 0,348 & $-3,237$ & 0,002 \\
\hline Kepemilikan Manajerial & 0,459 & 0,386 & 1,189 & 0,240 \\
\hline & \multicolumn{2}{|c|}{ Weighted Statistics } & & \\
\hline \multicolumn{5}{|c|}{$=5,578$} \\
\hline Sig. F & \multicolumn{4}{|c|}{$=0,002$} \\
\hline R Square & \multicolumn{4}{|c|}{$=0,259$} \\
\hline Adjusted R Square & \multicolumn{4}{|c|}{$=0,212$} \\
\hline \multicolumn{5}{|c|}{$Y=0,404+0,000 X_{1}-1,126 X_{2}+0,459 X_{3}+e$} \\
\hline
\end{tabular}

\section{Uji Hipotesis}




\section{Uji Signifikansi Simultan (Uji F)}

Uji statistik $\mathrm{F}$ bertujuan untuk menguji apakah semua varabel indpenden yang dimasukkan dalam model mempunyai pengaruh secara bersama-sama terhadap variabel dependen (Ghozali, 2013). Pada tabel 4.5 dapat dilihat bahwa hasil pengujian menunjukkan uji F memiliki signifikansi sebesar 0,002 lebih kecil dari 0,05 selain itu terlihat bahwa nilai Fhitung 5,578 lebih besar dari $F_{\text {tabel }}$ 2,79 maka dapat ditarik kesimpulan bahwa model regrei yang diperoleh layak untuk memprediksi agresivitas pajak yang dilakukan perusahaan. Nilai $F_{\text {tabel }}$ menggunakan tingkat keyakinan 95\%, alpha $5 \%$ dimana $F_{\text {tabel }}=(\mathrm{k} ; \mathrm{n}-\mathrm{k})$ atau $\mathrm{f}(3 ; 49)$, maka hasil untuk $\mathrm{F}_{\text {tabel }}=2,79$.

\section{Uji Signifikansi Parsial (Uji t)}

Uji statistik t digunakan untuk mengetahui ada atau tidaknya pengaruh masingmasing variabel independen secara individual terhadap variabel dependen yang diuji pada tingkat signifikansi 0,025. Jika nilai probabilitas t lebih kecil dari 0,025 maka H1 diterima dan $\mathrm{HO}$ ditolak, sedangkan jika nilai probabilitas t lebih besar dari 0,025 maka $\mathrm{H} 0$ diterima dan $\mathrm{H} 1$ ditolak.

Hipotesis pertama dalam penelitian ini adalah ukuran perusahaan berpengaruh terhadap agresivitas pajak. Pengujian hipotesis pertama dalam penelitian ini dilakukan untuk menguji apakah ukuran perusahaan mempengaruhi tindakan agresivitas pajak yang dilakukan perusahaan. Dari tabel 4.5 di atas, dapat dilihat bahwa untuk variabel ukuran perusahaan (X1) nilai t hitung 0,009 dan nilai tersebut lebih kecil dari t tabel sebesar $(0,009<2,01063)$ dengan signifikansi $>0,025$ $(0,993>0,025)$. Hal ini menunjukkan bahwa hipotesis H1 ditolak. Artinya secara parsial ukuran perusahaan tidak berpengaruh terhadap agresivitas pajak.

Hipotesis kedua dalam penelitian ini adalah karakter eksekutif berpengaruh terhadap agresivitas pajak. Pengujian hipotesis kedua dalam penelitian ini dilakukan untuk menguji apakah karakter eksekutif mempengaruhi tindakan agresivitas pajak perusahaan. Dari tabel 4.5 di atas, dapat dilihat bahwa untuk variabel karakter eksekutif (X2) nilai t hitung negatif 3,237 dan nilai tersebut lebih kecil dari t tabel sebesar $(1,999<2,01063)$ dengan signifikansi $<0,025(0,002<0,025)$. Hal ini menunjukkan bahwa hipotesis H2 diterima. Artinya secara parsial karakter eksekutif berpengaruh terhadap agresivitas pajak.

Hipotesis ketiga dalam penelitian ini adalah kepemilikan manajerial berpengaruh terhadap agresivitas pajak. Pengujian hipotesis ketiga dalam penelitian ini dilakukan untuk menguji apakah kepemilikan manajerial mempengaruhi tindakan agresivitas pajak perusahaan. Dari tabel 4.5 di atas, dapat dilihat bahwa untuk variabel kepemilikan manajerial(X3) nilai t hitung 1,189 dan nilai tersebut lebih kecil dari t tabel sebesar $(2,693>2,01063)$ dengan signifikansi $>0,025(0,240>0,025)$. Hal ini menunjukkan bahwa hipotesis H3 ditolak. Artinya secara parsial kepemilikan manajerial tidak berpengaruh terhadap agresivitas pajak.

\section{Koefisien Determinan (Adjusted $R^{2}$ )}

Koefisien Determinan digunakan untuk melihat kesesuaian model atau seberap besar kemampuan varabel bebas terhadap variabel terikatnya (Ghozali, 2013). Pada tabel 4.7 dapat dilihat nilai adjusted $R^{2}$ sebesar 0,212 yang berarti bahwa sebesar $21,2 \%$ agresivitas pajak dijelaskan oleh ukuran perusahaan, karakter eksekutif, dan kepemilikan manajerial, sedangkan sisanya sebesar 78,8\% agresivitas pajak dipengaruhi oleh variabel lain yang tidak dimasukkan ke dalam model analisis. 


\section{PEMBAHASAN}

Berdasarkan hasil analisis data yang telah dilakukan, diperoleh pembahasan pengaruh setiap variabel independen terhadap variabel dependen sebagai berikut:

\section{Pengaruh Ukuran Perusahaan terhadap Agresivitas Pajak}

Tingkat signifikansi ukuran perusahaan (X) sebesar sebesar 0,993 $>0,05$ berarti ukuran perusahaan tidak memiliki pengaruh terhadap agresivitas pajak. Hasil pengujian ini mengindikasi bahwa besar atau kecilnya perusahaan tidak mempengaruhi aktivitas agresivitas pajak. Kegiatan agresivitas pajak tidak hanya dilakukan oleh perusahaan besar saja, namun perusahaan dengan skala menengah atau kecilpun akan mampu melakukan tindakan agresivitas pajak, dikarenakan baik itu perusahaan besar atau kecil tetap dikenakan beban pajak. Perbedaannya terletak pada dampak penerimaan negara, jika agresivitas pajak dilakukan oleh perusahaan kecil, dampaknya tidak terlalu besar bagi penerimaan negara, karena jumlahnya tidak terlalu tinggi, sebaliknya jika dilakukan oleh perusahaan dengan skala besar, akan memiliki dampak yang besar terhadap penerimaan negara. Hasil penelitian ini sejalan dengan penelitian yang dilakukan oleh Annisa (2017) yang menemukan bahwa ukuran perusahaan tidak berpengaruh terhadap penghindaran pajak.

\section{Pengaruh Karakter Eksekutif terhadap Agresivitas Pajak}

Tingkat signifikansi karakter eksekutif $\left(\mathrm{X}_{2}\right)$ sebesar 0,002 $<0,05$. Hal itu menunjukkan bahwa karakter eksekutif berpengaruh terhadap agresivitas pajak. Artinya peningkatan tingkat risiko perusahaan akan meningkatkan tindakan agresivitas pajak yang dilakukan perusahaan. Hal ini sejalan dengan penelitian yang dilakukan oleh Dewi dan Jati (2014) yang menyatakan bahwa karakter eksekutif yang digambarkan dengan tingkat risiko yang dimiliki oleh perusahaan berpengaruh terhadap agresivitas pajak. Semakin seorang eksekutif bersifat risk taker maka semakin tinggi pula tingkat agresivitas pajak yang terjadi di perusahaan.

\section{Pengaruh Kepemiilikan Manajerial terhadap Agresivitas Pajak}

Tingkat signifikansi kepemilikan publik $\left(\mathrm{X}_{3}\right)$ sebesar $0.240>0.05$. Artinya hasil penelitian yang telah dilakukan menunjukkan kepemilikan manajerial tidak berpengaruh terhadap agresivitas pajak. Pemegang saham adalah orang yang memiliki suara dalam Rapat Umum Pemegang Saham (RUPS), namun tidak ikut dalam pengelolaan perusahaan. Tinggi atau rendahnya kepemilikan saham menunjukkan tingkat pengaruh yang dimiliki dalam menentukan kebijakan perusahaan. Apabila pihak manajerial sebagai pihak yang mengelola perusahaan juga menjadi pemegang saham, maka pihak manajerial dapat memiliki wewenang dalam menentukan pajak perusahaan. Akan tetapi, dalam penelitian ini ditemukan hasil yang bertolak belakang, dimana kepemilikan manajerial tidak berpengaruh terhadap tindakan agresivitas pajak. Tidak diterimanya hipotesis ini, disebabkan karena proporsi kepemilikan saham yang dimiliki pihak manajerial jauh lebih kecil dibanding dengan jumlah kepemilikan institusional. Hal tersebut mengindikasikan pihak manajerial tidak memiliki wewenang yang cukup besar dalam pengambilan keputusan perusahaan. Hasil penelitian ini sejalan dengan penelitan yang dilakukan oleh Hartadinata dan Tjaraka (2013) yang menyatakan bahwa kepemilikan manajerial tidak berpengaruh terhadap agrevitas pajak.

\section{KESIMPULAN DAN SARAN Kesimpulan}


Berdasarkan pengujian hipotesis yang dilakukan dapat disimpulkan hasil penelitian sebagai berikut: (1) Ukuran perusahaan tidak berpengaruh terhadap agresivitas pajak, (2) Karakter Eksekutif berpengaruh terhadap agresivitas pajak, dan (3) Kepemilikan manajerial tidak berpengaruh terhadap agresivitas pajak.

\section{Saran}

Berdasarkan beberapa keterbatasan penelitian yang telah di ungkapkan, maka peneliti memberikan saran untuk penelitian selanjutnya yaitu: (1) Penelitian selanjutnya diharapkan dapat memperluas populasi atau sampel penelitian selain sektor pertambangan dengan tujuan memperoleh keseragaman hasil penelitian, (2) Penelitian selanjutnya bisa menambah rentang waktu yang lebih panjang sehingga benar-benar melihat perilaku yang mempengaruhi tindakan agresivitas pajak yang dilakukan perusahaan, (3) Penelitian selanjutnya bisa menambahkan faktor-faktor lain yang diduga mempengaruhi tindakan agresivitas pajak perusahaan mengingat $78,8 \%$ dari nilai variabel independen dijelaskan oleh variabel lain diluar penelitian ini. Dan (4) Penelitian selanjutnya sebaiknya lebih memperhatikan karakter eksektif yang memiliki nilai risk taker lebih besar dan melihat kepemilikan lain selain kepemilikan manajerial.

\section{REFERENSI}

(1) Annisa (2017). Pengaruh Return On Asset, Ukuran Perusahaan, dan Koneksi Politik Terhadap Penghindaran Pajak. JOM Fekom Vol. 4 No.1.

(2) Ariyanti, Fiki. (2016). Realisasi Penerimaan Pajak 2015 Capai 81,5 dari Target. $\begin{array}{lllll}\text { Ditelusuri } & \text { pada } & 16 & \text { Juli } & 2018 .\end{array}$ https://www.liputan6.com/bisnis/read/2403217/realisasi-penerimaanpajak-2015-capai-815-dari-target

(3) Balakrishnan, Karthik, J. Blouin, and W. Guay. (2011). Does Tax Aggressiveness Reduce Financial Repoting Transparancy?.www. Google.co.id. Diakses Minggu 10 September 2017.

(4) Budiman, Judi. (2012). Pengaruh Karakter Eksekutif terhadap Penghindaran Pajak (Tax Avoidance). Jurnal Universitas Gadjah Mada.

(5) Bujaki, M.L. dan A.J. Richarson. (1997). A Citation Trail Review of The Uses of Firm Size in Accounting Research. Journal of Accounting Literature, Vol.16, pp 1-27.

(6) Chen et al. (2010). Are family firm more aggressive than non family firm ? Journal of Financial Economic. Vol 95

(7) Christiawan dan Tarigan (2007). Kepemilikan Manajerial : Kebijakan Hutang, Kinerja dan Nilai Perusahaan. Jurnal Ekonomi Akuntansi, Fakultas Ekonomi Universitas Kristen Petra.

(8) Deni, Septiany. (2017). Penerimaan Pajak Capai 81 Persen dari Target 2016. 
Ditelusuri

16

Juli

2018.

https://www.liputan6.com/bisnis/read/2693979/penerimaan-pajak-capai-

81-persen-dari-target-2016

(9) Desai, Mihir A. dan Dhammika Dharmapala. (2007). Taxation and Corporate Governance: An Economic Approach. http://www.interweb.org/londonmet/library/t77539 3.pdf.

(10) Dewi, Ni Nyoman Kristiana dan Ketut Jati. (2014). Pengaruh Karakter Eksekutif, Karakter Perusahaan, dan Dimensi Tata Kelola Perusahaan Yang Baik Pada Tax Avoidance: Studi Pada Perusahaan Manufaktur yang Terdaftar di Bursa Efek Indonesia. E-Jurnal Akuntansi Universitas Udayana 6.2 (2014):249260

(11) Eisenhardt, Kathleen M. (1989). Agency Theory: An Assessment and Review. Academy of Management. Vol. 14, No. 1 (Jan., 1989), pp. 57-54

(12) Frank, M.M., Lynch, LJ,. \& Rego, S.0. (2009). Tax Reporting Aggressiveness and Its Relation to Aggressive Financial Reporting. The Accounting Review, 84. (2). Hal 467-696.

(13) Ghozali, Imam. (2013). Aplikasi Analisis Multivariate dengan Program SPSS. Semarang :Badan Penerbit Universitas Diponegoro

(14) Hartadinata, Oka S. Dan Heru Tjaraka (2013). Analisis Pengaruh Kepemilikan Manajerial, Kebijakan Hutang, dan Ukuran Perusahaan Terhadap Tas Agressiveness. Studi Pada Perusahaan Manufaktur di Bursa Efek Indonesia Periode 2008-2010. Jurnal Ekonomi Binis.

(15) Hlaing, K.P. (2012). Organizational Architecture of Multinationals and Tax Aggressiveness. University of Waterloo. Canada

(16) Jensen, M. (1976). Agency Cost of Free Cash Flow, Corporate Finance and Rakeover, American Economic Review, Vol.76, pp.323-329

(17) Jensen, M.C. dan William H. Meckling. (1976). Theory of The Firm: Managerial Behavior, Agency Cost and Ownership Sturture. Journal of Financial Economics, pp. 205-360

(18) Kusuma, Hendra. (2018). Penerimaan Perpajakan 2017 Capai 1.339 Triliun, 91\% dari Target. Ditelusuri 16 Juli 2018. https://finance.detik.com/beritaekonomi-bisnis/d-3795760/penerimaan-perpajakan-2017-capai-rp-1339triliun-91-dari-target

(19) Low, Angie. (2008). Managerial Risk-Taking Behavior and Equity-Based Compensation. Fisher College of Business Working Paper September 2006, 03003.

(20) Paligorova, T. (2010). Corporate Risk Taking and Ownership Structure. Ottawa, 
Ontario: Bank of Canada

(21) Putri, Citra Lestari dan Maya Febrianty Lautania (2016). Pengaruh Capital Intensity Ratio, Inventory Intensity Ratio, Ownership Sturcture dan Profitability Terhadap Effective Tax Rate (ETR). Junal Ilmial Mahasiswa Ekonomi Akuntansi (JIMEKA), Vol. 1, No. 1, (2016) Halaman: 110-119

(22) Richardson, G. Dan R. Lanis. (2007). Determinants of The Variability in Corporate Effective Tax Rates and Tax Reform : Evidence from Australia. Journal of Accounting and Public Policy, 26 (2007), 689-704.

(23) Richardson, G. Dan R. Lanis. (2012). Corporate Social Responsibility and Tax Aggresiveness: a test of legitimacy theory. Accounting Auditing and Accountability Journal, Vol.26, No. 1,hal.75-100.

(24) Rohmansyah, Budi. (2017). Determinan Kinerja Perusahaan Terhadap Agresivitas Pajak. Studi Pada Perusahaan Sektor Perbankan yang Terdaftar di Bursa Efek Indoesia Periode 2010-2014.

(25) Slemrod, Joel. (2004). The Economic of Corporate Tax Selfishness. Journal of Public Economic 1.

(26) Timothy, Y. C. K. (2010). Effect of Corporate Governance on Tax Aggressiveness. Thesis Hong Kong Baptist University.

(27) Tiaras, Irvan. dan Wijaya, Henryanto. (2015). Pengaruh Likuiditas, Leverage, Manajemen Laba, Komisaris Independen dan Ukuran Perusahaan Terhadap Agresivitas Pajak. Jurnal Akuntansi, Vol. XIX, No. 03, September 2015, Hlm. 380-397

(28) Waluyo, Agus. (2015). Realisasi Penerimaan Pajak 2014 Terendah dalam 25 Tahun Terakhir. $\quad$ Ditelusuri $16 \quad$ Juli 2018. https://ekonomi.kompas.com/read/2015/01/14/122832126/Realisasi.Pajak. 2014.Terendah.dalam.25.Tahun.Terakhir

(29) Yoehana, Maretta. (2013). Analisis Pengaruh Corporate Sosial Responsibility Terhadap Agresivitas Pajak. Studi Empiris Pada Perusahaan Manufaktur yang Terdaftar di BEI Pada Tahun 2010-2011 